\title{
Gene Expression Response of the Non-target Gastropod Physella Acuta to Fenoxycarb, a Juvenile Hormone Analog Pesticide
}

\section{Patricia Caballero}

UNED: Universidad Nacional de Educacion a Distancia

Marina Prieto-Amador

UNED: Universidad Nacional de Educacion a Distancia

Jose-Luis Martinez-Guitarte ( $\boldsymbol{D}$ jlmartinez@ccia.uned.es )

Universidad Nacional de Educacion a Distancia https://orcid.org/0000-0002-7722-864X

\section{Research Article}

Keywords: pesticide, non-target species, array, transcriptional activity

Posted Date: November 22nd, 2021

DOI: https://doi.org/10.21203/rs.3.rs-1036012/v1

License: (c) (i) This work is licensed under a Creative Commons Attribution 4.0 International License.

Read Full License 


\section{Abstract}

Nowadays, pesticides are an environmental problem because they can act on non-target species. Therefore, the search for new pest control methods has focused on compounds with low or no toxic effects. Analogs of the juvenile hormone are one such group of pesticides since they work by interfering in the endocrine system of arthropods. However, the lack of effect on non-target species is frequently assumed, and it requires confirmation. This article analyzes the impact of Fenoxycarb, an analog of juvenile hormone, on Physella acuta, an aquatic gastropod. Animals exposed for one week to $0.01,1$, and $100 \mu \mathrm{g} / \mathrm{L}$ were used to obtain RNA and perform retrotranscription and real-time PCR. Forty genes related to the endocrine system, the DNA repair mechanisms, the different phases of detoxification, oxidative stress, the stress response, the nervous system, hypoxia, energy metabolism, the immune system, and apoptosis were analyzed. Three of the genes, AchE, Hsp17.9, and ApA, showed responses to the presence of Fenoxycarb at $1 \mu \mathrm{g} / \mathrm{L}$, with no statistically significant responses in the rest of the genes and at the remaining concentrations. From the results it can be concluded that Fenoxycarb shows low toxicity in Physella acuta. However, the fact that a gene related to immunity was altered prevents any conclusions in relation to the putative long-term effects that this juvenile hormone analog could have. Therefore, additional research would be necessary to confirm the safety of Fenoxycarb in non-arthropod species.

\section{Introduction}

The pesticide Fenoxycarb (IUPAC: ethyl [2-(4-phenoxy-phenoxy)ethyl] carbamate, CAS No. 72490-01-8) is a carbamate used to control various insect pests in crops and ornamental cultures (Sullivan 2010). It regulates insect growth by mimicking the juvenile hormone, preventing the insect from reaching maturity (Dhadialla et al. 1998). It is considered not harmful to vertebrates and non-target species, affecting insects and crustaceans exclusively (Arambourou et al. 2017; Navis et al. 2018; Jindra and Bittova 2020). Furthermore, Fenoxycarb is considered environmentally safe because of its rapid degradation (Schaefer et al. 1987), with a dissipation time 50 (DT ${ }_{50}$ ) of 4.13 days in the water column and 15 days in sediment (PPDB database, (Sullivan 2010)). It has a low drift to adjacent lands from fields where it is applied (Thomas et al. 2016), although it may end up in surface waters due to spray drift, runoff, or drainage (Jungmann et al. 2009).

In vertebrates, no effect on reproduction in sheep was observed (Barr et al. 1997), but it has been described that in cultured rat cortical neurons exposed for one week, Fenoxycarb considerably decreased ATP levels, mitochondrial membrane potential, and glucose consumption (Schmuck and Mihail 2004). Furthermore, it inhibits rat brain acetylcholinesterase and nicotinic acetylcholine receptors expressed in Xenopus laevis oocytes (Smulders et al. 2003). On the other hand, some reports show that it can negatively affect egg production and the hatching rate in the collembola Yuukianura szeptyckii (Lee et al. 2020), although previous studies on Folsomia candida did not show such an effect (Campiche et al. 2006). Similarly, adverse effects such as inhibition of molting and body length growth were observed when the shrimp Neocaridina davidi was exposed for two weeks to concentration as low as $10 \mu \mathrm{g} / \mathrm{L}$ (Hu et al. 2019), while the crab Rhithropanopeus harrisii experienced delayed metamorphosis at $48 \mu \mathrm{g} / \mathrm{L}$ of 
Fenoxycarb (Cripe et al., 2003). Taking together these results, additional studies are required to know the impact of this pesticide on ecosystems. There is a lack of information on the effects of Fenoxycarb on non-arthropod freshwater invertebrates, but it is expected to be harmless to them. However, the paucity of knowledge of the physiology of invertebrates, especially regarding the endocrine system, requires confirmation of this extreme. This work aims to test the toxicity of Fenoxycarb at the transcription level, in the freshwater gastropod Physella acuta (Draparnaud, 1805) by exposing the animals for one week and analyzing the transcription profile with an array covering different relevant cellular pathways.

The freshwater snail Physella acuta, also known as Physa acuta, is a hermaphroditic and cosmopolitan species. It lives in lakes and ponds and lays its eggs in an egg mass that requires around two weeks to develop. The hatched juveniles grow for two months until they reach the adult stage, mate, and lay eggs. The species is easily cultured in the laboratory, so it is used in toxicity studies as representative of the gastropods (Sánchez-Argüello et al. 2009, 2012). Recently, we designed an array to study the response to toxicants at the gene expression level in this species (Prieto-Amador et al., 2021). It included 34 genes and 4 reference genes. In addition, we extended it to 40 target genes, including some of them to analyze the alterations at the transcriptional activity level in several cellular processes. The sequence of nine genes is described for the first time for this species and extends the number of genes that can be used as biomarkers. The sequences code for proteins related to the endocrine system (galanin receptor type 2, estrogen-related receptor, membrane progestin receptor-beta, estradiol 17-beta-dehydrogenase 8, and retinoic acid receptor RXR), DNA repair (poly-ADP-ribose polymerase I, DNA repair protein XRCC3, lkBa), and stress response (heat shock protein 70 B2-like). Overall, the array allows analysis of alterations in the endocrine system, detoxification mechanisms, DNA repair, the nervous system, apoptosis, oxidative stress, stress, epigenetics, the immune system, energy metabolism, and lipid transport. In this way, the array shows changes in the main mechanisms involved in the response to stress and detoxification but also the response of processes involved in long-term effects, such as epigenetic modification mechanisms and DNA repair, that would be activated in case of any genotoxic effect of the compound.

As stated, the work aims to assess the putative toxicity of Fenoxycarb in Physella acuta exposed for one week to environmentally relevant concentrations by analyzing different processes involved in the shortand long-term response, and some of them, such as the endocrine system and the immune system, involved in relevant physiological mechanisms to survive.

\section{Material And Methods}

\subsection{Chemicals}

Fenoxycarb was purchased from Sigma-Aldrich (Germany). In addition, TRIzol and M-MLV enzyme were obtained from Invitrogen (Germany), oligonucleotide dT18 primer and gene-specific primers were supplied by Macrogen (Korea), RNase-free DNase was purchased from Sigma (Germany), DNA polymerase and dNTPs were obtained from Biotools (Spain), and EvaGreen was purchased from Biotium (USA). 


\subsection{Animals}

The populations of Physella acuta were grown in the laboratory for numerous generations. They were established from animals provided by Dr. Sánchez-Argüello (Instituto Nacional de Investigación y Tecnología Agraria y Alimentaria, Spain). The gelatinous egg masses were collected and allocated in 500 $\mathrm{ml}$ glass vessels with $250 \mathrm{ml}$ of culture medium $\left(2 \mathrm{mM} \mathrm{CaCl}_{2}, 0.5 \mathrm{mM} \mathrm{MgSO}_{4}, 0.77 \mathrm{mM} \mathrm{NaHCO}_{3}\right.$, and $0.08 \mathrm{mM} \mathrm{KCl}$ ). The medium was changed twice per week, and the animals were fed twice per week with a mixture of Shrimps Natural (Sera) and Micron Nature (Sera). The cultures were maintained at $18 \pm 1^{\circ} \mathrm{C}$ under a $16 \mathrm{~h}$ light:8 $\mathrm{h}$ dark cycle.

\subsection{Treatment}

The experiments were performed by exposing six adult snails $(0.091 \pm 0.01 \mathrm{~g}$ and $0.79 \pm 0.08 \mathrm{~cm})$ per vessel. Fenoxycarb was diluted in acetone for a final stock of $100 \mathrm{mg} / \mathrm{mL}$. The stock was diluted to final concentrations of $0,0.01,1$, and $100 \mu \mathrm{g} / \mathrm{L}(0,0.031,3.31$, and $331.8 \mathrm{nM}$ respectively). The exposure was performed in glass vessels with $300 \mathrm{~mL}$ of culture medium. The control was performed with the solvent at the same concentration of treatments, 1:10,000. The medium was changed after three days with Fenoxycarb, and the animals were fed with $18 \mathrm{mg}$ of the food mixture ( $3 \mathrm{mg} /$ animal). In each experiment, three of the snails were recovered for mRNA analysis per concentration. Four experiments were performed, giving $\mathrm{n}=12$ for each concentration.

\subsection{Sequence identification and primer design}

As previously stated, most of the array genes have been described in another article (Prieto-Amador et al. 2021). They are summarized in table S1. Nine genes are described here for the first time. The sequences were isolated from a transcriptome obtained in the laboratory (Aquilino et al. 2019) and the sequences published by (Romiguier et al. 2014), which are available on the web (http://kimura.univmontp2.fr/PopPhyl/index.php? section = data\# dataset_0). The sequences obtained from the transcriptome and Romiguier et al. were identified by blasting them to the database using the txblast tool, a non-redundant database, and an e-value threshold of 1e-3. The search was performed with OmicsBox [OmicsBox - Bioinformatics made easy (Version 2.0.29). BioBam Bioinformatics. March 3, 2019. https://www.biobam.com/omicsbox]. The identified sequences were translated with Snapgene software (GSL Biotech LLC, USA), and the protein was compared with the GenBank protein database to confirm the identity of the gene. Estrogen-related receptor, IkBa, and DNA repair protein XRCC3 were identified from sequences published by Romiguier et al., while Galanin receptor type 2, membrane progestin receptor beta, estradiol 17-beta-dehydrogenase 8, Retinoic acid receptor RXR, poly-ADP-ribose polymerase I, and Heat shock protein 70 B2-like were obtained from the transcriptome. The accession numbers of transcriptome sequences are OK474807 (GalR), OK474808 (mPRbeta), OK474809 (HSDB17B8), OK474810 (RXR), OK474811 (PARP1), and OK474812 (HSP70B2).

Primers were designed using Primer-Blast (Ye et al., 2012). The amplicon size was $100-200 \mathrm{bp}$, and the optimal melting temperature was $58^{\circ} \mathrm{C}$. All primer pairs were tested by polymerase chain reaction (PCR) 
in a C1000 thermocycler (Bio-Rad, USA) with DNA AmpliTools Green Master Mix (Biotools, Spain). The single band was confirmed by gel electrophoresis (1.5\% agarose gel). The PCR program was the same as that used for real-time PCR (RT-PCR).

\subsection{RNA extraction and retrotranscription}

Frozen adults were used to perform the RNA extraction. Each animal was processed individually. TRIzol extraction was performed by following the manufacturer's indications. Briefly, the sample was homogenized, and then chloroform was added to the sample and incubated for three minutes at room temperature. Afterward, the sample was centrifuged for 10 minutes and the upper phase recovered. The RNA was precipitated with 0.7 volumes of isopropanol and washed with $75 \%$ ethanol. The RNA was resuspended in diethylpyrocarbonate-treated water and incubated for 45 minutes with RNAse-free DNAse (Roche, Germany). A phenol: chloroform treatment was performed with Phase-Lock tubes (5prime, USA) to remove the DNAse. The RNA was precipitated again with isopropanol and resuspended in 100 microliters of DEPC-treated water.

Retrotranscription was performed with MMLV (Invitrogen, Germany) in a final volume of $40 \mu \mathrm{l}$ with $10 \mu \mathrm{g}$ of RNA following the manufacturer's indications. The primer used was a poly $\mathrm{T}_{18}$. The retrotranscribed sample was maintained at $-20^{\circ} \mathrm{C}$ until use.

\subsection{Real-Time PCR}

RT-PCR was performed using a 96-well plate with 40 target genes and 4 reference genes, so each gene was analyzed in duplicate. First, the efficiency of each primer pair was established by amplifying the sequence by PCR employing the same conditions as in RT- PCR. Then, a 1:25000 dilution was performed by mixing the PCRs of array genes, mimicking the variety of sequences in an RNA extraction. Finally, a five dilution series was used to obtain the efficiency curve with the same program as used for RT-PCR (see below).

First, the primers were added to each well (250 nM each). Then, a master mix with the cDNA (8 $\mu \mathrm{L}$ per plate), Evagreen (0.5x), dNTPs $(0.2 \mathrm{mM}), 1 \times$ buffer, and $2.5 \mathrm{mM} \mathrm{MgCl}$, was prepared, and 10 microliters were added to each well. Two technical replicates were performed for each sample. The program used was an initial denaturation at $95^{\circ} \mathrm{C}$ for 2 minutes and then $95^{\circ} \mathrm{C}$ for 15 seconds, $58^{\circ} \mathrm{C}$ for 30 seconds, and $72^{\circ} \mathrm{C}$ for 15 seconds, repeated 39 times. After that, a melting curve from 60 to $85^{\circ} \mathrm{C}$ was constructed with $0.5^{\circ} \mathrm{C}$ steps to confirm the presence of a single product. To establish the cycle threshold, the regression option was used in the Maestro software (BioRad, USA). The Ct was the value used for subsequent analysis of the data.

\subsection{Statistics}

The statistical analysis was performed in SPSS 25 (IBM, USA). The data showed no normal distribution when the Shapiro-Wilk test was performed; therefore, the non-parametric Kruskal-Wallis test was used for 
data analysis. The level of significance was set at $p \leq 0.05$. The number of samples per condition was $n$ $=12$. Statistically significant changes relative to the control were considered as alterations.

\section{Results}

\subsection{Identification of sequences}

Nine sequences were identified that code for different proteins related to the endocrine system (estradiol 17-beta-dehydrogenase 8 , estrogen related receptor, galanin receptor type 2 , membrane progestin receptor-beta, and retinoic acid receptor), the stress response (heat shock protein 70 B2-like), and DNA repair mechanisms (DNA repair protein XRCC3, NF-kappa-B inhibitor alpha, and poly-ADP-ribose polymerase I). The size of the sequence and the ORF size are shown in Table 1. Furthermore, the identity and similarity at the amino acid level with the indicated protein are shown. The database comparison showed homology with proteins from other mollusks, mainly gastropods, except for membrane progestin receptor beta, which was homologous to a protein of bivalve origin. The degree of homology was high except in the case of the galanin receptor and the membrane progestin receptor-beta, while ERR and HSP70 B2 showed more than 90\% identity. Figure 1 shows the scheme of the proteins with the different motifs that characterize them. All of them showed the characteristic domains associated with those proteins, so it can be concluded that the isolated sequences correspond to the genes coding those proteins. 
Table 1

Information of the sequences described for first time. DNA and protein size, homology, identity, and similarity are indicated. The contig number or accession number are indicated.

\begin{tabular}{|c|c|c|c|c|c|c|}
\hline & Gene & $\begin{array}{l}\text { Size } \\
\text { bp } \\
\text { (DNA) }\end{array}$ & $\begin{array}{l}\text { Size } \\
\text { aa } \\
\text { (prot) }\end{array}$ & Homology & $\begin{array}{l}\text { Identity } \\
\text { (\%) }\end{array}$ & $\begin{array}{l}\text { Similarity } \\
(\%)\end{array}$ \\
\hline \multirow[t]{2}{*}{ Contig11036 } & $\begin{array}{l}\text { DNA repair } \\
\text { protein XRCC3 }\end{array}$ & 1273 & 345 & $\begin{array}{l}\text { PREDICTED: DNA repair } \\
\text { protein XRCC3-like } \\
\text { isoform X1 - } \\
\text { Biomphalaria glabrata }\end{array}$ & 58 & 72 \\
\hline & & & & XP_013089306 & & \\
\hline \multirow[t]{2}{*}{ OK474809 } & $\begin{array}{l}\text { estradiol 17- } \\
\text { beta- } \\
\text { dehydrogenase } \\
8\end{array}$ & 1055 & 253 & $\begin{array}{l}17 \text { beta-hydroxysteroid } \\
\text { dehydrogenase } 8 \text { - } \\
\text { Lymnaea stagnalis }\end{array}$ & 78 & 90 \\
\hline & & & & QNG40045 & & \\
\hline \multirow[t]{2}{*}{ Contig1634 } & $\begin{array}{l}\text { Estrogen } \\
\text { related } \\
\text { receptor }\end{array}$ & 3125 & 443 & $\begin{array}{l}\text { PREDICTED: steroid } \\
\text { hormone receptor ERR2- } \\
\text { like isoform X3 - } \\
\text { Biomphalaria glabrata }\end{array}$ & 91 & 96 \\
\hline & & & & XP_013080351 & & \\
\hline \multirow[t]{2}{*}{ OK474807 } & $\begin{array}{l}\text { Galanin } \\
\text { receptor type } 2\end{array}$ & 2066 & 525 & $\begin{array}{l}\text { PREDICTED: galanin } \\
\text { receptor type 2-like - } \\
\text { Biomphalaria glabrata }\end{array}$ & 38 & 55 \\
\hline & & & & XP_013071428 & & \\
\hline \multirow[t]{2}{*}{ OK474812 } & $\begin{array}{l}\text { Heat shock } \\
\text { protein } 70 \text { B2- } \\
\text { like }\end{array}$ & 2486 & 636 & $\begin{array}{l}\text { PREDICTED: heat shock } \\
\text { protein } 70 \text { B2-like - } \\
\text { Biomphalaria glabrata }\end{array}$ & 91 & 96 \\
\hline & & & & XP_013072147 & & \\
\hline \multirow[t]{2}{*}{ Contig8155 } & $\begin{array}{l}\text { NF-kappa-B } \\
\text { inhibitor alpha }\end{array}$ & 1611 & 377 & $\begin{array}{l}\text { PREDICTED: NF-kappa- } \\
\text { B inhibitor alpha-like- } \\
\text { Biomphalaria glabrata }\end{array}$ & 57 & 74 \\
\hline & & & & XP_013067082 & & \\
\hline \multirow[t]{2}{*}{ OK474808 } & $\begin{array}{l}\text { membrane } \\
\text { progestin } \\
\text { receptor beta }\end{array}$ & 2308 & 340 & $\begin{array}{l}\text { membrane progestin } \\
\text { receptor beta-like - } \\
\text { Mizuhopecten } \\
\text { yessoensis }\end{array}$ & 39 & 58 \\
\hline & & & & XP_021341591 & & \\
\hline \multirow[t]{2}{*}{ OK474811 } & $\begin{array}{l}\text { poly-ADP- } \\
\text { ribose } \\
\text { polymerase I }\end{array}$ & 3162 & 991 & $\begin{array}{l}\text { poly-(ADP-ribose) } \\
\text { polymerase I - Aplysia } \\
\text { californica }\end{array}$ & 77 & 87 \\
\hline & & & & NP_001191521 & & \\
\hline
\end{tabular}




\begin{tabular}{|lllllll|}
\hline & Gene & $\begin{array}{l}\text { Size } \\
\text { bp } \\
\text { (DNA) }\end{array}$ & $\begin{array}{l}\text { Size } \\
\text { aa } \\
\text { (prot) }\end{array}$ & Homology & $\begin{array}{l}\text { Identity } \\
\text { (\%) }\end{array}$ & $\begin{array}{l}\text { Similarity } \\
\text { (\%) }\end{array}$ \\
\hline OK474810 & $\begin{array}{l}\text { Retinoic acid } \\
\text { receptor RXR }\end{array}$ & 3551 & 435 & $\begin{array}{l}\text { Retinoic acid receptor } \\
\text { RXR - Lymnaea } \\
\text { stagnalis } \\
\text { Q517G2 }\end{array}$ & 96 & 97 \\
\hline
\end{tabular}

\subsection{Gene expression profile in response to Fenoxycarb exposure}

Adult snails were exposed to $0.01,1$, and $100 \mu \mathrm{g} / \mathrm{L}$ of Fenoxycarb for seven days to assess the mid-term response of the genes analyzed (figures 2 to 6 and S1-S2). Fenoxycarb is an analog of juvenile hormone that is not expected to affect non-arthropods. There was no statistically significant response in those genes related to the endocrine system (figure 2), DNA repair mechanisms (figure 3), oxidative stress (figure 4), apoptosis (figure 4), phase I (figure S1), phase II (figure S2), and phase III (figure S2) of detoxification, most stress proteins (figure 5), hypoxia (figure 5), epigenetic regulation (figure 6), and energy metabolism (figure 6). Only three genes were modified at $1 \mu \mathrm{g} / \mathrm{L}$ : acetylcholinesterase (chi square=-16.144, $p=0.029$; figure 4), HSP 17.9 (chi square $=-15.553, p=0.039$; figure 5), and aplysianin $A$ (chi square $=-20.333, p=0.002$; figure 6). Therefore, the two genes analyzed in relation to the nervous system and immunity showed some alteration, suggesting some mid-term effects on the physiology of $P$. acuta.

\section{Discussion}

Advances in toxicological studies demand the extension of toxicity tests to additional levels beyond traditional endpoints such as survival, reproduction, or development. Nowadays, a molecular approach to toxicity evaluation is frequently taken, and it requires additional putative biomarkers that assess the modulation of different cellular processes and physiological mechanisms (Lee et al. 2015; Martins et al. 2019; Steiblen et al. 2020). In this sense, adding new genes to the battery of biomarkers extends the number of processes studied and the levels of response, depending on the pathway analyzed. Therefore, the description new genes is a step toward extending the value of Physella acuta in toxicological studies. Here we have described nine new sequences that code for different hormone receptors, an enzyme involved in regulating the concentration of active estrogens and androgens (estradiol 17-betadehydrogenase 8), one stress protein, and three proteins involved in the DNA repair. These genes can improve the analysis of different processes related to endocrine disruption, genotoxicity, and development. Furthermore, all of them can help us to understand the response on different levels of organization, from molecular to ecological, providing insights into the mechanisms of the toxicant and the responses of the organisms to maintain homeostasis in the face of a changing environment. On the other hand, these putative biomarkers open new ways to assess toxicity prior to its observation at the 
individual level, preventing irreversible damage that affects the population. Thus, as in clinical practice, new tools are required to better identify molecular events and obtain an earlier diagnosis that will help to detect pollution before it causes irreversible damaging effects on ecosystems.

For a long time, the search for pesticides with either low or no impact on non-target species has been a key agricultural aim. Analogs of the juvenile hormone have been one such pesticide since they mimic one specific hormone of arthropods, drastically reducing the risk to other species (Wilson 2004). It is known that Fenoxycarb affects the development and different cell processes in insects, arachnids, and crustaceans (Jungmann et al. 2009; Navis et al. 2018; Lee et al. 2020). However, the current poor knowledge of invertebrate physiology makes it necessary to test them in non-target species to ensure their low impact. The first element to consider is the fact that the response is observed at $1 \mu \mathrm{g} / \mathrm{L}$ of Fenoxycarb, which is the intermediate concentration used. It is very low compared to those that have an effect on insects and crustaceans (Cripe et al. 2003; Mahmoudvand and Moharramipour 2015; Hu et al. 2019). The lack of response at higher concentrations can be due to an earlier response, recovering the normal condition to the time of the analysis by the action of detoxification mechanisms. At the lower concentration, the lack of observed response could be due to the amount of toxicant being below the threshold concentration needed to trigger an effect. Another possibility could be that more time is necessary to reach the threshold concentration. Additional research employing different response times would allow elucidation of the cellular processes affected and the concentration-dependent consequences.

In this work, we have tested the response at the gene expression level of the analog of juvenile hormone, Fenoxycarb and observed a response that, although weak, demands additional studies to ensure the lack of toxicity in non-arthropods. As expected, no effect was observed in genes related to DNA repair mechanisms or the stress response. There are no data in the literature on studies of these genes, even in insects. A similar situation happens with energy metabolism, although there are some reports about the impact of fenoxycarb in lipids and carbohydrates of crustaceans (Arambourou et al. 2018; Hu et al. 2019, 2020). As far as we know, there is no previous report analyzing the response of detoxification mechanisms in the presence of Fenoxycarb. In $P$. acuta there is no change in the genes analyzed involved in phase I, phase II, and phase III of detoxification, suggesting that other proteins different from those analyzed here are responsible for the biotransformation of this chemical. In contrast to our results, with no changes in genes related to epigenetic regulation, it has been described that exposure for three days at $50 \mu \mathrm{g} / \mathrm{L}$ of Fenoxycarb can upregulate histone deacetylase in the water flea Moina macrocopa (Hu et al. 2020). This could reflect differential sensitivity to the compound but also the fact that the epigenetic changes in the water flea are related to mimicking of the juvenile hormone effects.

The effect on the acetylcholinesterase gene suggests some impact on the nervous system. As stated in the introduction, inhibition on rat brain acetylcholinesterase activity and nicotinic receptors have been observed (Smulders et al. 2003), suggesting that Fenoxycarb can have nervous effects on non-target organisms. Studies in nicotinic receptors showed that the mechanism of Fenoxycarb was noncompetitive (Smulders et al. 2004). Although Fenoxycarb has been used as an analog of juvenile hormone, it seems 
to also have some effect as the rest of carbamates by affecting the nervous system. The response observed in $P$. acuta supports a nervous effect and suggests that it could affect the ability of the snail to survive by altering the central nervous system. The increase observed in the transcription could be reflecting and attempt to compensate the inhibition on enzyme activity. Additional studies would help elucidate the putative effect on the snail's behavior or ability to respond to situations involving the nervous system. In any case, it is a fact to consider in the impact that Fenoxycarb can have in non-target species in the mid- and long-term.

On the other hand, the modulation of SHSP17.9 suggests some effect, but to determine the real impact on the cell is a complex matter. Small heat shock proteins are diverse proteins involved in the stress response and related to multiple cellular processes, including neural functions (de Los Reyes and CasasTintó 2022). In this sense, it is tempting to speculate that SHSP17.9 could encode some sHSP involved in neural physiology but the difficulties to establish the homology demand caution. Additional research will provide more information and could help to define the role of this protein in the cell. As biomarkers, the fact that SHSPs share the alpha-crystallin domain makes it easy to identify them. However, their high diversity in the $\mathrm{N}$ - and $\mathrm{C}$-terminal regions complicate the identification of homologies between species. Consequently, a deeper study of this protein family is required to determine their roles in cell metabolism and to establish functional homologies between them. In any case, the alteration observed suggests that Fenoxycarb has some effect in the mid-term in Physella acuta, raising the possibility that it causes some reduction in the wellness of the snail.

Aplysianin-A is a protein involved in the immune response by acting as an antibacterial. This antibacterial glycoprotein inhibits both gram-positive and gram-negative bacteria in Aplysia kurodai (Kamiya et al. 1986). The alteration in transcriptional activity can produce a modulation of the response to bacterial infections, making $P$. acuta more sensitive to them. The impact observed in $P$. acuta suggests a putative alteration in immunity, being the first time that this possibility is suggested for Fenoxycarb. Additional studies involving more immune related genes are needed to confirm it and determine the effect in the long term survival of the population.

\section{Conclusions}

Safety at the environmental level is a concern of all the products used as pesticides. The search for new pesticides with a reduced impact in non-target species demands testing in these species because some of them can have low impact. However, the lack of knowledge about the physiology of invertebrates requires experimental work to confirm it. It will also provide additional information about the physiology of the invertebrates, decreasing the gap with the vertebrates and favoring the use of invertebrates as alternative methods that reduce the use of vertebrates in the test of toxicity. The present evidence suggests a low impact for the environment of Fenoxycarb, but the results observed in the non-target species Physella acuta requires an extended analysis because it can reflect an impact at the long-term as a consequence of the exposure. To ensure the harmless of the Fenoxycarb, it should be analyzed in several non-target species covering different groups of invertebrates. 


\section{Declarations}

\section{Acknowledgments}

This work was supported by Programa Estatal de I+D+i Orientada a los Retos de la Sociedad (Spain), Grant RTI2018-094598-B-100 from the Ciencias y Tecnologías Medioambientales program. M.P. received a research assistant contract from Plan Empleo Juvenil, Comunidad de Madrid (PEJ-2019-Al/AMB12448); and P.C. received a predoctoral contract from Plan de Empleo Juvenil, Comunidad de Madrid (PEJD-2019-PRE/AMB-14815), both co-funded by Consejeria de Educación e Investigación (Comunidad de Madrid) and the European Social Fund (ESF). The authors declare that they have no conflict of interest.

\section{Ethical Approval}

Not applicable.

\section{Consent to Participate}

Not applicable.

\section{Consent to Publish}

Not applicable.

\section{Availability of data and materials}

The datasets used and/or analysed during the current study are available from the corresponding author on reasonable request.

\section{Funding}

This work was supported by Programa Estatal de I+D+i Orientada a los Retos de la Sociedad (Spain), Grant RTI2018-094598-B-100 from the Ciencias y Tecnologías Medioambientales program. M.P. received a research assistant contract from Plan Empleo Juvenil, Comunidad de Madrid (PEJ-2019-AI/AMB12448); and P.C. received a predoctoral contract from Plan de Empleo Juvenil, Comunidad de Madrid (PEJD-2019-PRE/AMB-14815), both co-funded by Consejeria de Educación e Investigación (Comunidad de Madrid) and the European Social Fund (ESF).

\section{Author contributions.}

J-L. M-G. conceived and designed the analysis, wrote the paper, and contributed to data analysis. M. P-A. and P. C. collected the data and contributed to data analysis.

\section{Competing Interests Statement}


The authors declare no competing interests.

\section{References}

1. Aquilino M, Sánchez-Argüello P, Novo M, Martínez-Guitarte J-L (2019) Effects on tadpole snail gene expression after exposure to vinclozolin. Ecotoxicol Environ Saf 170:568-577. https://doi.org/10.1016/j.ecoenv.2018.12.015

2. Arambourou H, Decamps A, Quéau H, et al (2017) Use of Gammarus fossarum (Amphipoda) embryo for toxicity testing: A case study with cadmium. Environ Toxicol Chem. https://doi.org/10.1002/etc.3779

3. Arambourou H, Fuertes I, Vulliet E, et al (2018) Fenoxycarb exposure disrupted the reproductive success of the amphipod Gammarus fossarum with limited effects on the lipid profile. PLoS One 13:e0196461. https://doi.org/10.1371/journal.pone.0196461

4. Barr AC, Abbitt B, Fiske RA, et al (1997) Reproductive effects of fenoxycarb on sheep. J Vet Diagn Invest 9:401-406. https://doi.org/10.1177/104063879700900410

5. Campiche S, Becker-van Slooten K, Ridreau C, Tarradellas J (2006) Effects of insect growth regulators on the nontarget soil arthropod Folsomia candida (Collembola). Ecotoxicol Environ Saf 63:216-225. https://doi.org/10.1016/j.ecoenv.2005.07.004

6. Cripe GM, McKenney CL, Hoglund MD, Harris PS (2003) Effects of fenoxycarb exposure on complete larval development of the xanthid crab, Rhithropanopeus harrisii. Environ Pollut 125:295-299. https://doi.org/10.1016/s0269-7491(02)00414-1

7. de Los Reyes T, Casas-Tintó S (2022) Neural functions of small heat shock proteins. Neural Regen Res 17:512-515. https://doi.org/10.4103/1673-5374.320975

8. Dhadialla TS, Carlson GR, Le DP (1998) New insecticides with ecdysteroidal and juvenile hormone activity. Annu Rev Entomol 43:545-569. https://doi.org/10.1146/annurev.ento.43.1.545

9. Hu XL, Niu JJ, Meng Q, et al (2019) Effects of two juvenile hormone analogue insecticides, fenoxycarb and methoprene, on Neocaridina davidi. Environmental Pollution 253:89-99. https://doi.org/10.1016/j.envpol.2019.06.120

10. Hu XL, Tang YY, Kwok ML, et al (2020) Impact of juvenile hormone analogue insecticides on the water flea Moina macrocopa: Growth, reproduction and transgenerational effect. Aquat Toxicol 220:105402. https://doi.org/10.1016/j.aquatox.2020.105402

11. Jindra M, Bittova $L$ (2020) The juvenile hormone receptor as a target of juvenoid "insect growth regulators." Arch Insect Biochem Physiol 103:e21615. https://doi.org/10.1002/arch.21615

12. Jungmann D, Bandow C, Gildemeister T, et al (2009) Chronic toxicity of fenoxycarb to the midge Chironomus riparius after exposure in sediments of different composition. Journal of Soils and Sediments 9:94-102. https://doi.org/10.1007/s11368-009-0056-2

13. Kamiya H, Muramoto K, Yamazaki M (1986) Aplysianin-A, an antibacterial and antineoplastic glycoprotein in the albumen gland of a sea hare,Aplysia kurodai. Experientia 42:1065-1067. 
https://doi.org/10.1007/BF01940736

14. Lee JW, Won E-J, Raisuddin S, Lee J-S (2015) Significance of adverse outcome pathways in biomarker-based environmental risk assessment in aquatic organisms. Journal of Environmental Sciences 35:115-127. https://doi.org/10.1016/j.jes.2015.05.002

15. Lee Y-S, Son J, Wee J, et al (2020) A reconsideration of the safety of fenoxycarb (IGR) in soil environment: The toxicity of fenoxycarb to Yuukianura szeptyckii (Collembola). Journal of AsiaPacific Entomology 23:214-218. https://doi.org/10.1016/j.aspen.2019.12.006

16. Mahmoudvand M, Moharramipour S (2015) Sublethal Effects of Fenoxycarb on the Plutella xylostella (Lepidoptera: Plutellidae). J Insect Sci 15:82. https://doi.org/10.1093/jisesa/iev064

17. Martins C, Dreij K, Costa PM (2019) The State-of-the Art of Environmental Toxicogenomics: Challenges and Perspectives of "Omics" Approaches Directed to Toxicant Mixtures. Int J Environ Res Public Health 16:E4718. https://doi.org/10.3390/ijerph16234718

18. Navis S, Waterkeyn A, De Meester L, Brendonck L (2018) Acute and chronic effects of exposure to the juvenile hormone analog fenoxycarb during sexual reproduction in Daphnia magna. Ecotoxicology 27:627-634. https://doi.org/10.1007/s10646-018-1935-3

19. Prieto-Amador M, Caballero P, Martínez-Guitarte J-L (2021) Analysis of the impact of three phthalates on the freshwater gastropod Physella acuta at the transcriptional level. Sci Rep 11:11411. https://doi.org/10.1038/s41598-021-90934-9

20. Romiguier J, Gayral P, Ballenghien M, et al (2014) Comparative population genomics in animals uncovers the determinants of genetic diversity. Nature 515:261-263. https://doi.org/10.1038/nature13685

21. Sánchez-Argüello P, Aparicio N, Fernández C (2012) Linking embryo toxicity with genotoxic responses in the freshwater snail Physa acuta: single exposure to benzo(a)pyrene, fluoxetine, bisphenol A, vinclozolin and exposure to binary mixtures with benzo(a)pyrene. Ecotoxicol Environ Saf 80:152-160. https://doi.org/10.1016/j.ecoenv.2012.02.029

22. Sánchez-Argüello P, Fernández C, Tarazona JV (2009) Assessing the effects of fluoxetine on Physa acuta (Gastropoda, Pulmonata) and Chironomus riparius (Insecta, Diptera) using a two-species water-sediment test. Sci Total Environ 407:1937-1946. https://doi.org/10.1016/j.scitotenv.2008.12.004

23. Schaefer $\mathrm{CH}$, Wilder WH, Mulligan FS, Dupras EF (1987) Efficacy of fenoxycarb against mosquitoes (Diptera: Culicidae) and its persistence in the laboratory and field. J Econ Entomol 80:126-130. https://doi.org/10.1093/jee/80.1.126

24. Schmuck G, Mihail F (2004) Effects of the carbamates fenoxycarb, propamocarb and propoxur on energy supply, glucose utilization and SH-groups in neurons. Arch Toxicol 78:330-337. https://doi.org/10.1007/s00204-004-0546-3

25. Smulders CJGM, Bueters TJH, Van Kleef RGDM, Vijverberg HPM (2003) Selective effects of carbamate pesticides on rat neuronal nicotinic acetylcholine receptors and rat brain 
acetylcholinesterase. Toxicol Appl Pharmacol 193:139-146.

https://doi.org/10.1016/j.taap.2003.07.011

26. Smulders CJGM, Van Kleef RGDM, de Groot A, et al (2004) A noncompetitive, sequential mechanism for inhibition of rat alpha4beta2 neuronal nicotinic acetylcholine receptors by carbamate pesticides. Toxicol Sci 82:219-227. https://doi.org/10.1093/toxsci/kfh261

27. Steiblen G, Benthem J van, Johnson G (2020) Strategies in genotoxicology: Acceptance of innovative scientific methods in a regulatory context and from an industrial perspective. Mutat Res Genet Toxicol Environ Mutagen 853:503171. https://doi.org/10.1016/j.mrgentox.2020.503171

28. Sullivan JJ (2010) Chemistry and environmental fate of fenoxycarb. Rev Environ Contam Toxicol 202:155-184. https://doi.org/10.1007/978-1-4419-1157-5_3

29. Thomas K, Resseler H, Spatz R, et al (2016) A simple approach for a spatial terrestrial exposure assessment of the insecticide fenoxycarb, based on a high-resolution landscape analysis. Pest Manag Sci 72:2099-2109. https://doi.org/10.1002/ps.4338

30. Wilson TG (2004) The molecular site of action of juvenile hormone and juvenile hormone insecticides during metamorphosis: how these compounds kill insects. J Insect Physiol 50:111-121. https://doi.org/10.1016/j.jinsphys.2003.12.004

\section{Figures}

Poly-ADP-ribose polymerase I

1

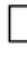

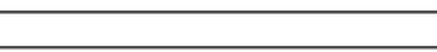

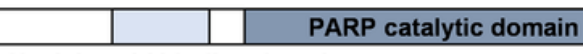

Nucleic acid binding domain

Heat shock protein 70 B2-like

1

| HSPA1-2_6-8-like_NBD

HSP70

Galanin receptor type 2

1

\section{7tmA_Trissin_R}

525

\section{Estrogen related receptor}

1

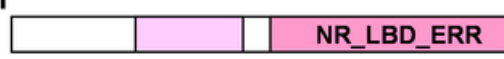

NR_DBD_ERR

\section{Retinoic acid receptor}

1
NF-kappa- $\beta$ inhibitor alpha-like

991

1

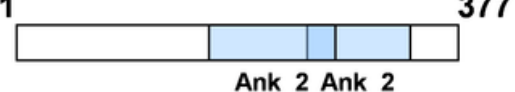

DNA repair protein XRCC3

1

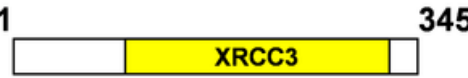

Membrane progestin receptor beta

1

Haemolysin-III related

340

Estradiol 17-beta-dehydrogenase 8

BKR_SDR_c
253
1

443

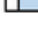


Structure and conserved domains of the Physella acuta proteins code by the sequences identified. The characteristic motifs of each protein are shown. The domains have been defined according to the Conserved Domains Database (CCD) functional classification of proteins. The size is indicated by the numbers.
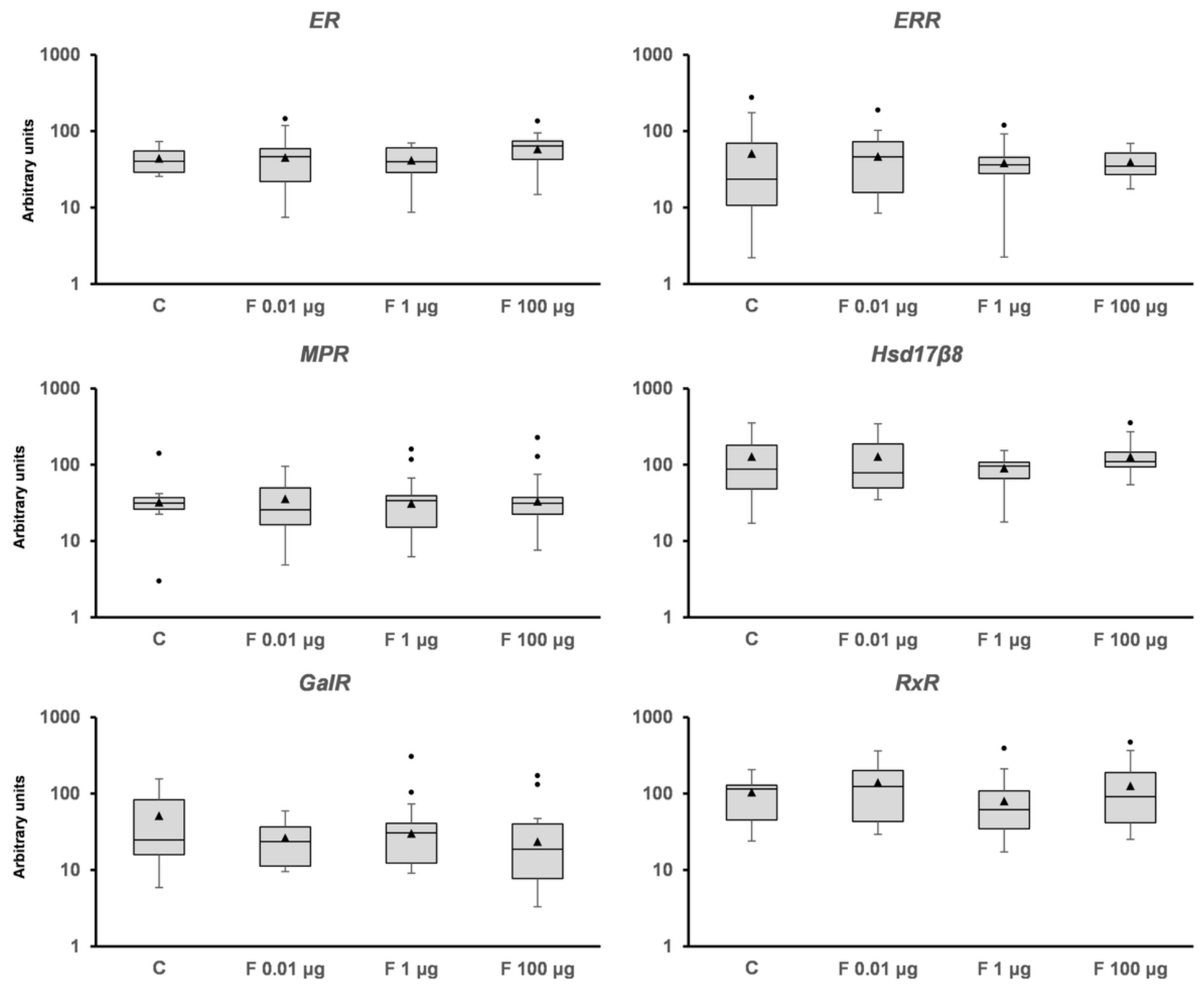

\section{Figure 2}

Transcript levels of endocrine-related sequences (estrogen receptor, estrogen-related receptor, membrane progestin receptor beta, estradiol 17-beta-dehydrogenase 8 , galanin receptor, and retinoic acid receptor) in Physella acuta adults after in vivo exposure to Fenoxycarb for seven days at $19{ }^{\circ} \mathrm{C}$. Transcriptional activity was quantified by RT-PCR using rpL10, Act, PFKFB2, and GAPDH as reference genes. The comparison was performed with the solvent-exposed controls. Whisker boxes are shown. Each box corresponds to 12 individuals. The median is indicated by the horizontal line within the box, and the 25th and 75th percentiles are indicated by the boundaries of the box. The highest and lowest results are 
represented by the whiskers. The small triangle inside the box denotes the mean, and the outliers are shown (circles). No significant differences to control were observed in those genes $(p<0.05)$.

PARP

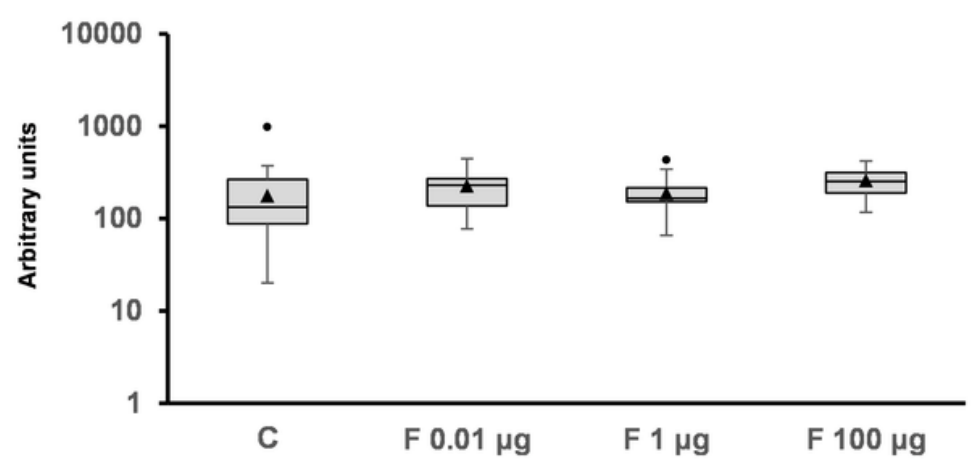

XRCC3
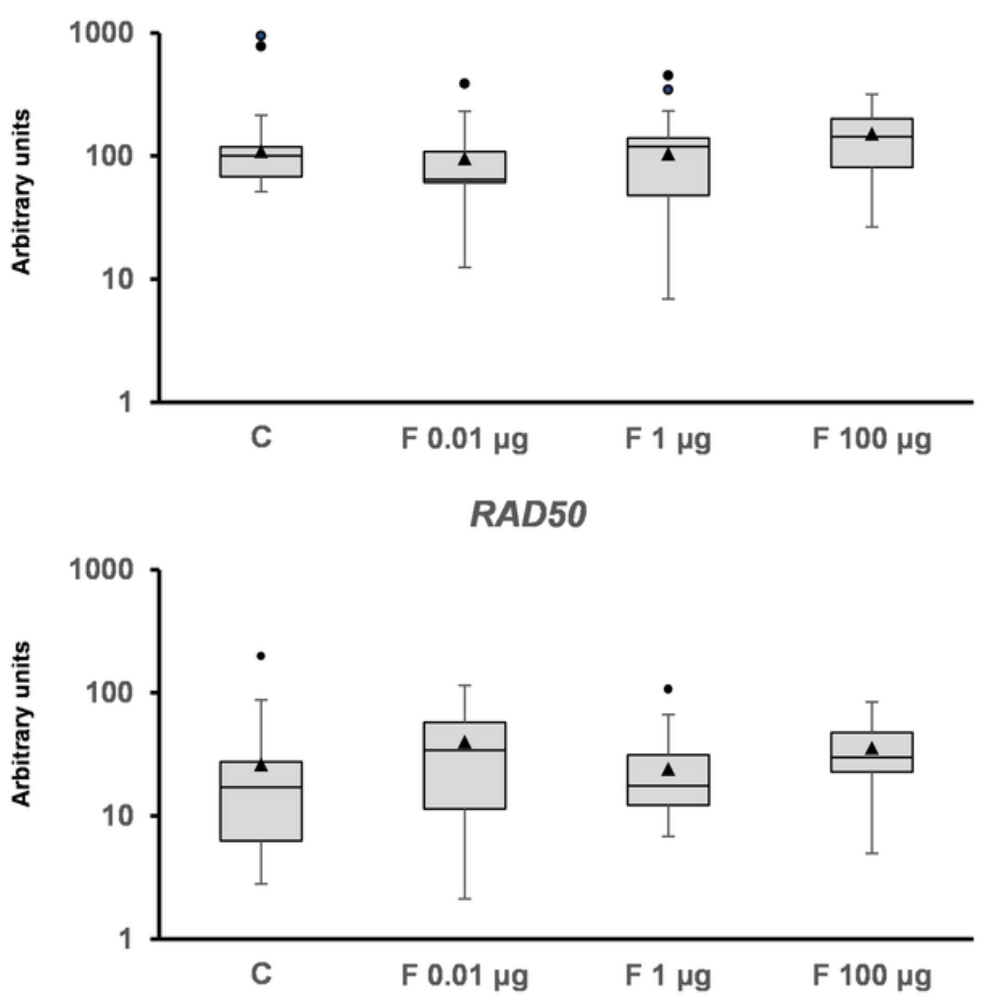

IK $\boldsymbol{\beta}$

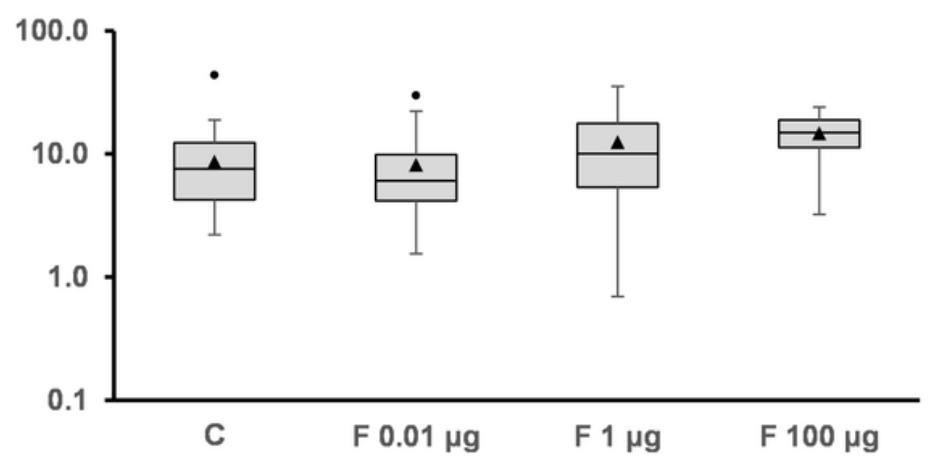

RAD21

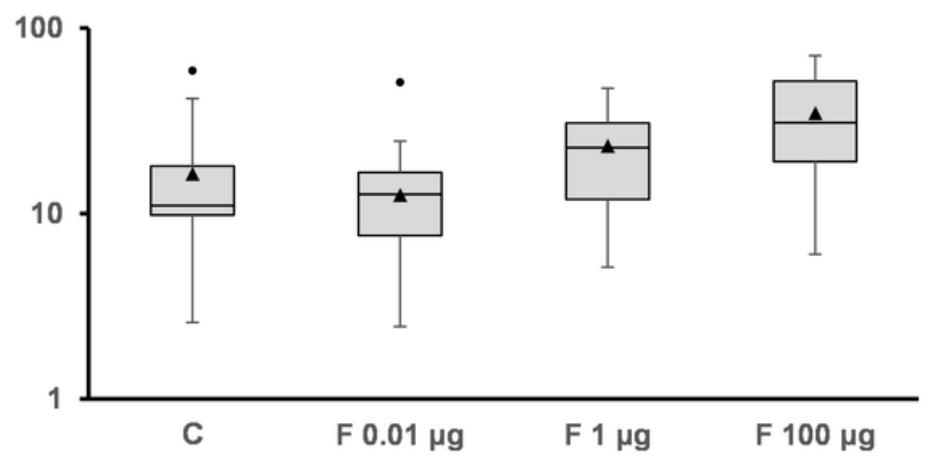

\section{Figure 3}

Transcriptional activity of genes related to DNA repair. The mRNA levels of poly(ADP-Ribose) polymerase, NFKB inhibitor IK $\beta$, X-ray repair cross complementing 3, RAD21, and RAD50 in Physella acuta adults after in vivo exposure to Fenoxycarb for seven days at $19{ }^{\circ} \mathrm{C}$ are shown. RT-PCR was used to quantify the mRNA levels and rpL10, Act, PFKFB2, and GAPDH were used as reference genes. The comparison was performed with the solvent-exposed controls. Whisker boxes are shown. Each box corresponds to 12 individuals. The median is indicated by the horizontal line within the box, and the 25th and 75th percentiles are indicated by the boundaries of the box. The highest and lowest results are represented by the whiskers. The small triangle inside the box denotes the mean, and the outliers are shown (circles). No significant differences were observed relative to the control $(p<0.05)$. 

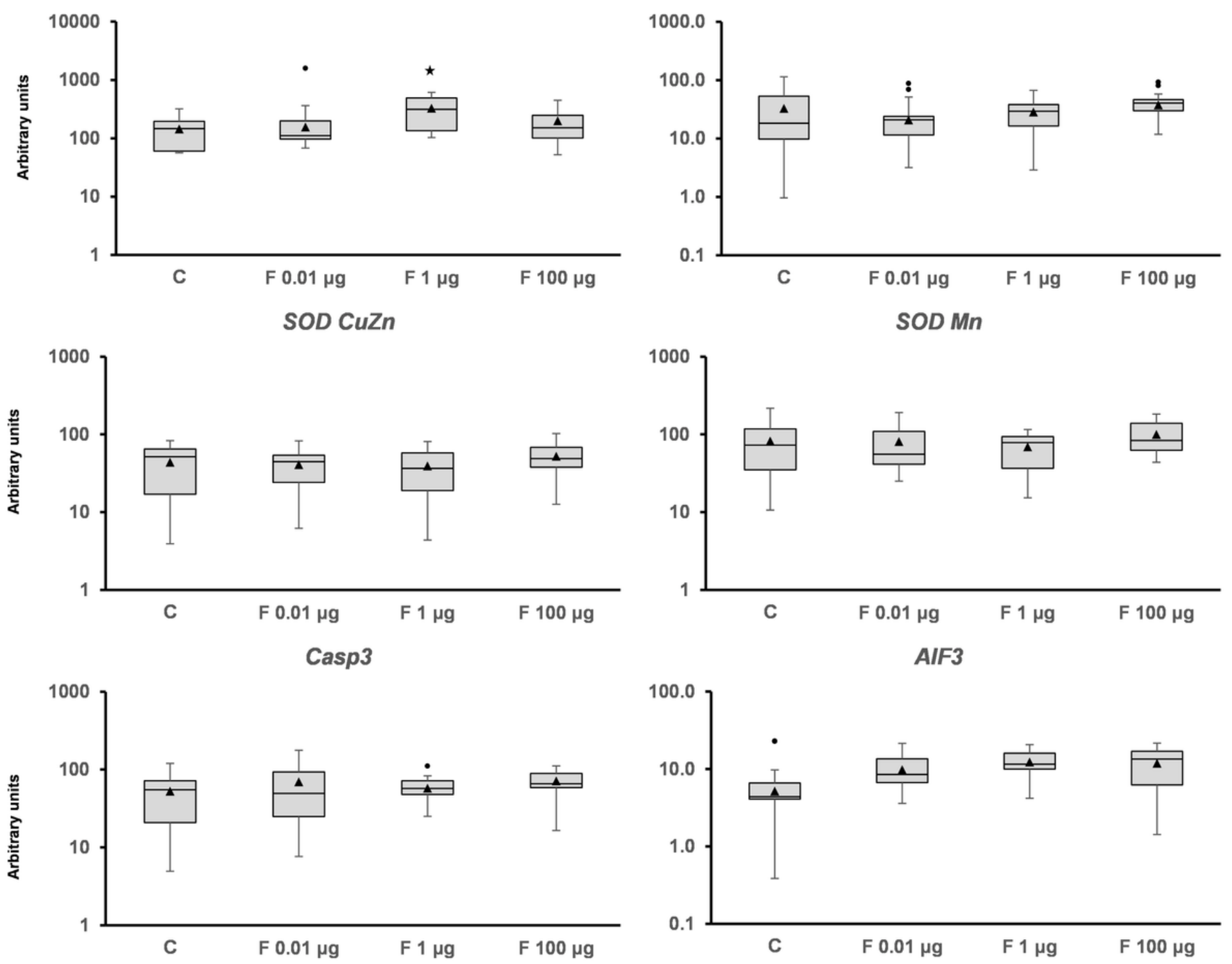

Figure 4

Transcriptional activity of genes related to the nervous system (acetylcholinesterase), oxidative stress (catalase, copper-zinc superoxide dismutase, and manganese superoxide dismutase), and apoptosis (caspase 3 and apoptosis inducing factor 3 ). Snails were exposed to Fenoxycarb for seven days at $19{ }^{\circ} \mathrm{C}$. Quantification by RT-PCR was performed using rpL10, Act, PFKFB2, and GAPDH as reference genes. The comparison was performed with the solvent-exposed controls. Whisker boxes are shown. Each box corresponds to 12 individuals. The median is indicated by the horizontal line within the box, and the 25th and 75th percentiles are indicated by the boundaries of the box. The highest and lowest results are represented by the whiskers. The small triangle inside the box denotes the mean, and the outliers are shown (circles). Significant difference relative to the control (asterisk) is indicated $(p<0.05)$. 
sHSP16.6
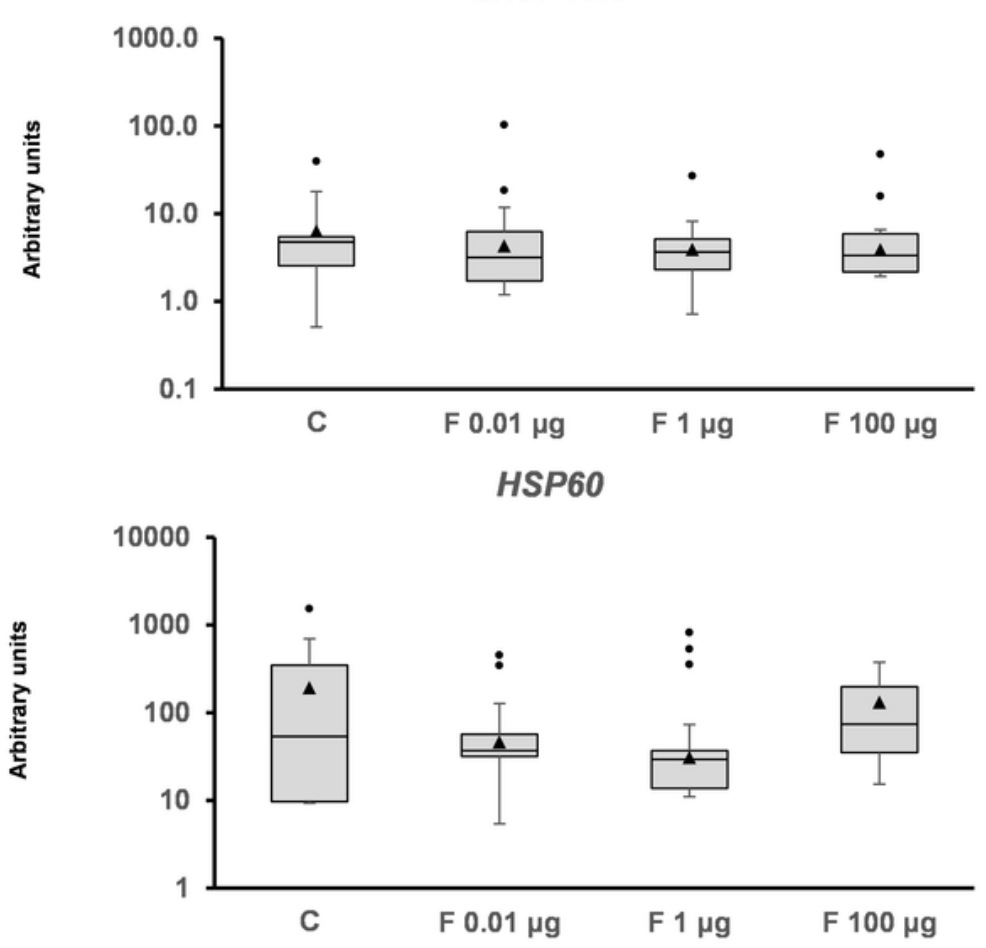

HSP70B2
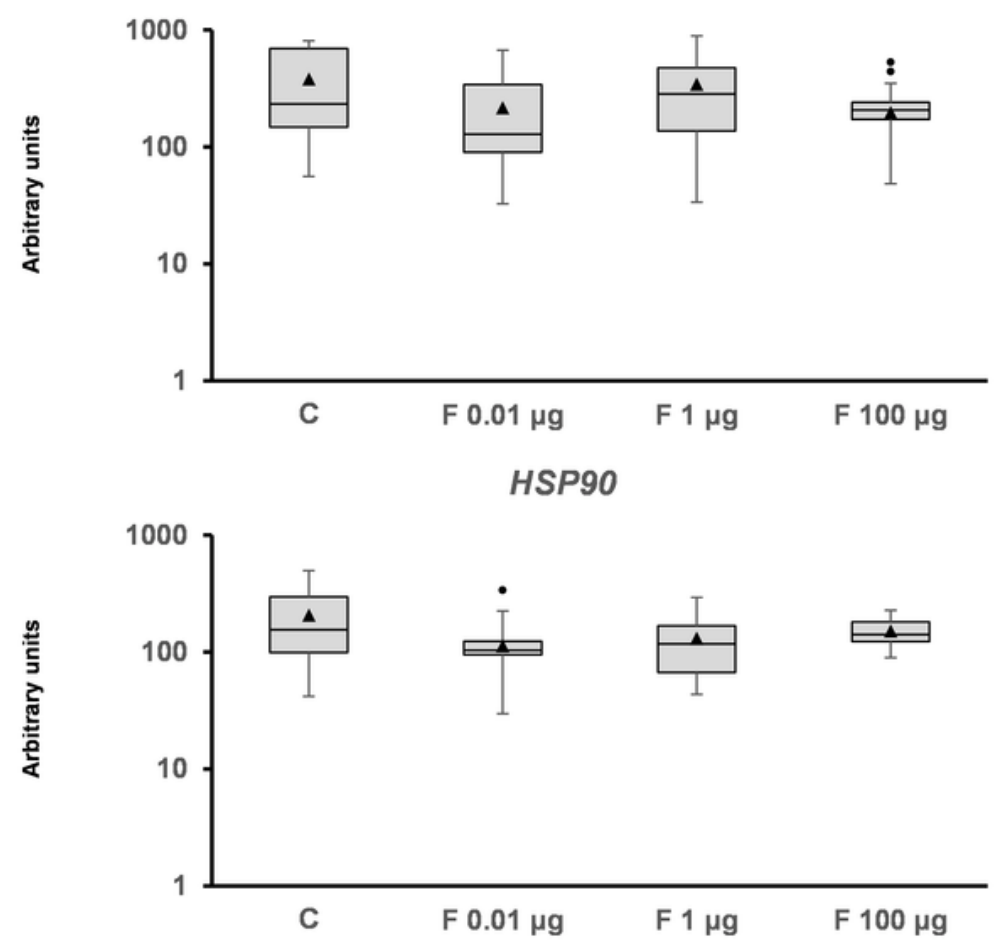

sHSP17.9
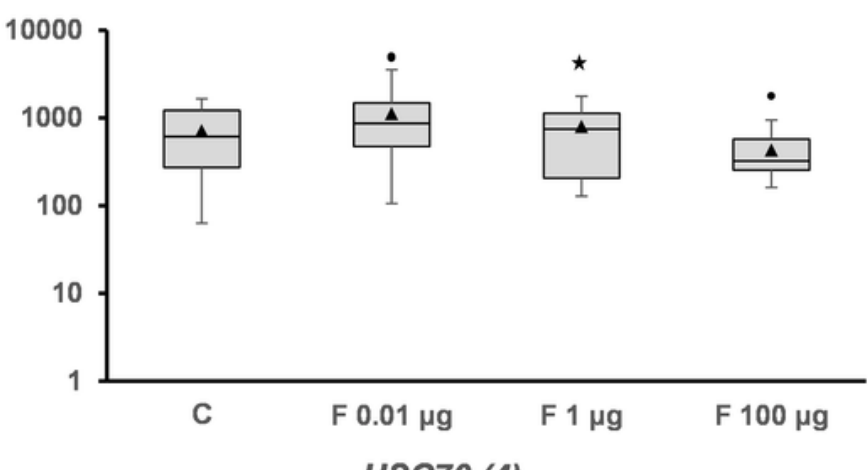

HSC70 (4)

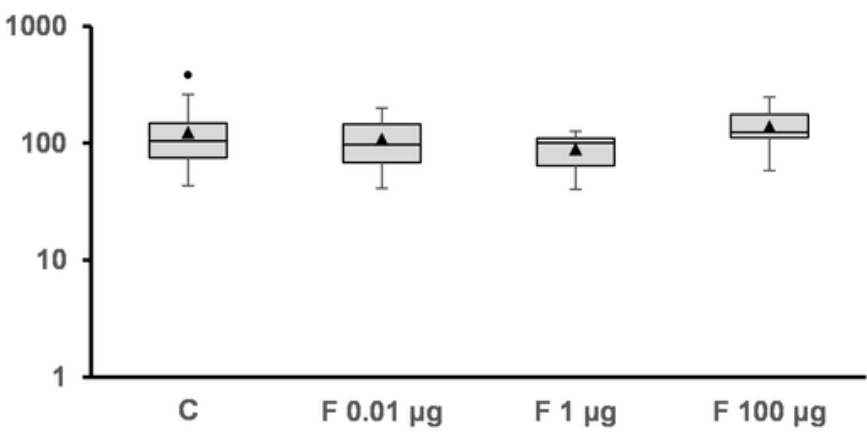

Grp78/Bip

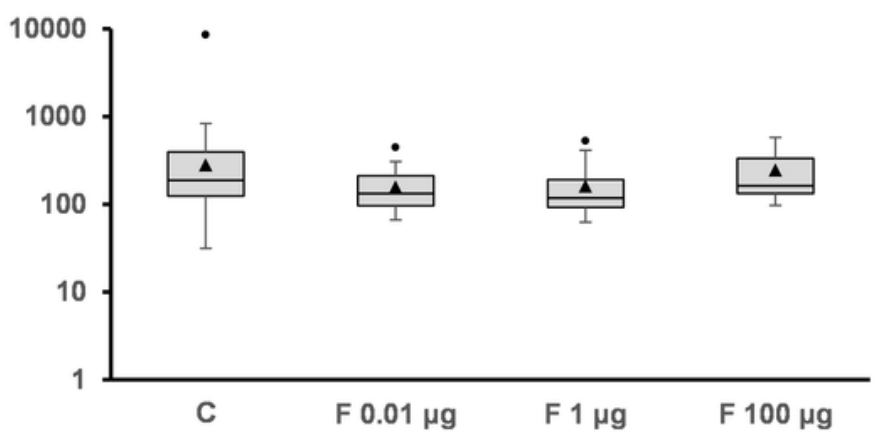

HIF1a

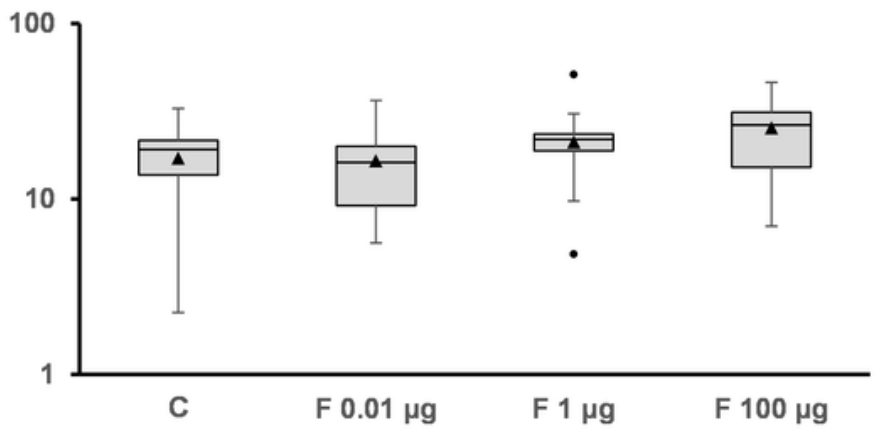

\section{Figure 5}

Transcriptional activity of stress (sHSP16.6, sHSP17.9, HSP60, HSC70 (4), HSP70B2, Grp78/BiP, and HSP90) and hypoxia (HIF1a) genes in adult snails. The animals were exposed for one week to Fenoxycarb at $19^{\circ} \mathrm{C}$. Transcriptional activity was quantified by RT-PCR using rpL10, Act, PFKFB2, and GAPDH as reference genes. The comparison was performed with the solvent-exposed controls. Whisker boxes are shown. Each box corresponds to 12 individuals. The median is indicated by the horizontal line 
within the box, and the 25th and 75th percentiles are indicated by the boundaries of the box. The highest and lowest results are represented by the whiskers. The small triangle inside the box denotes the mean, and the outliers are shown (circles). Significant difference relative to the control (asterisk) is indicated ( $p<$ 0.05).
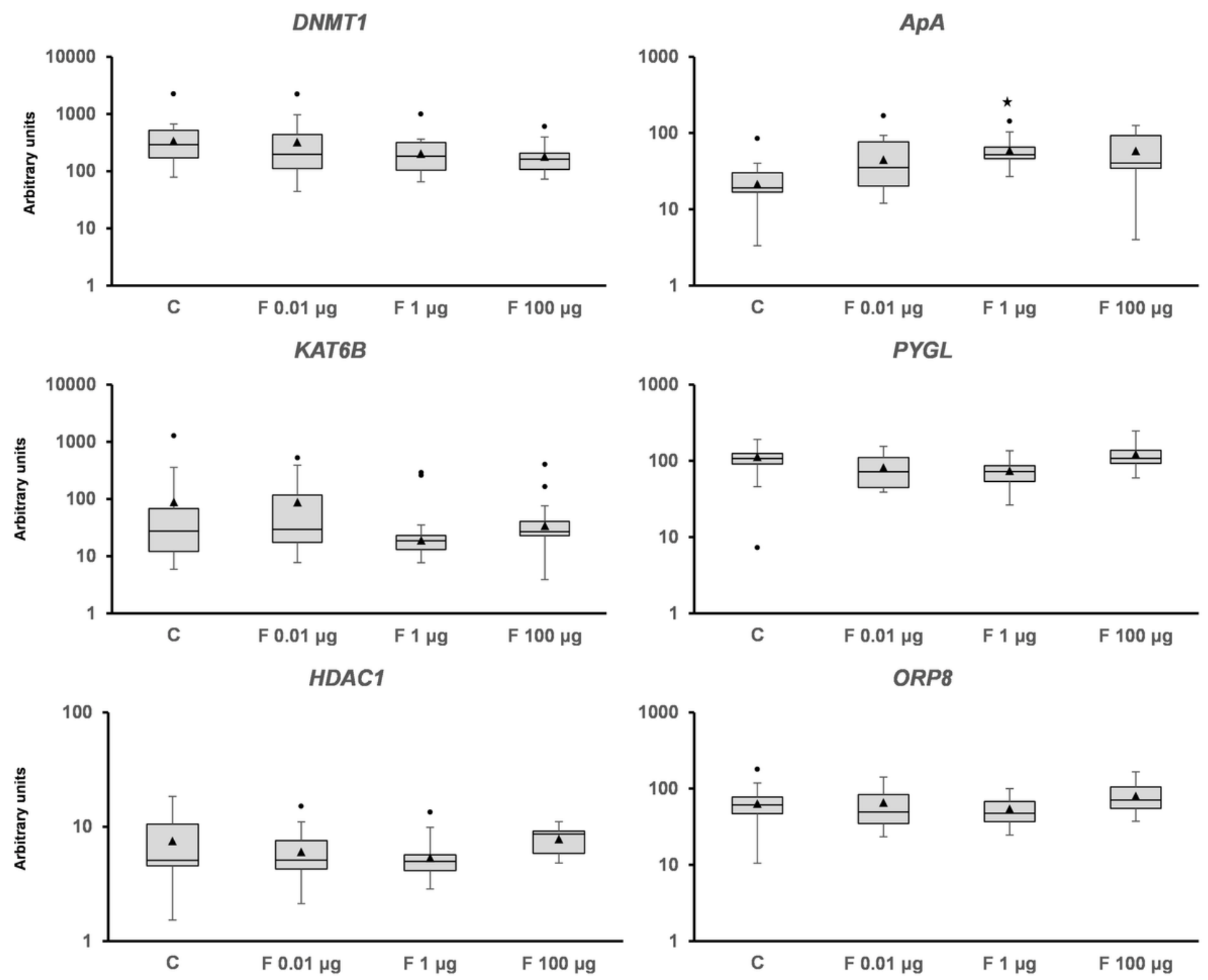

\section{Figure 6}

Transcriptional activity of genes related to epigenetic modulation (DNA methylase I, Lysine Acetyltransferase 6B, and histone deacetylase 1), immunity (aplysianin-A), and energy metabolism (glycogen phosphorylase $L$ and oxysterol binding protein like 8 ) in Physella acuta adults after in vivo exposure to Fenoxycarb for seven days at $19{ }^{\circ} \mathrm{C}$. Transcriptional activity was quantified by RT-PCR using rpL10, Act, PFKFB2, and GAPDH as reference genes. The comparison was performed with the solventexposed controls. Whisker boxes are shown. Each box corresponds to 12 individuals. The median is indicated by the horizontal line within the box, and the 25th and 75th percentiles are indicated by the boundaries of the box. The highest and lowest results are represented by the whiskers. The small triangle 
inside the box denotes the mean, and the outliers are shown (circles). Significant difference relative to the controls (asterisk) is indicated $(p<0.05)$.

\section{Supplementary Files}

This is a list of supplementary files associated with this preprint. Click to download.

- SupplementarymaterialESPR.docx 